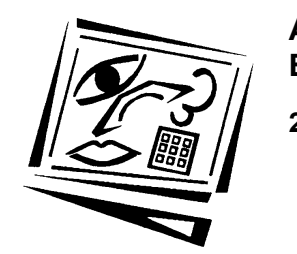

\title{
Investigating design and technology students' peer interactions in a technology-mediated learning environment: A case study
}

Tiong Meng Yeo and Choon Lang Quek

Nanyang Technological University

\begin{abstract}
This research investigates students' peer interactions in the Design and Technology (D\&T) environment supported by Knowledge Forum. The sample comprised of 15 students who had no prior experience in using Knowledge Forum to mediate their D\&T learning. Their interaction with peers occurred in three stages: design situation, ideation and development. Data was collected mainly from students' online discussion transcripts, with reference to hardcopy of students' reflection logs and design briefs which were analysed quantitatively and qualitatively. The findings showed unequal participation by the students throughout their weekly online discussion activities. In terms of students' interaction with their peers, the frequency of students' reading of notes far exceeded their frequency of building upon notes, as evidenced by their social network of notes.
\end{abstract}

\section{Introduction}

Participation and interaction are key learning processes in a technology-mediated environment. An initial study conducted on 15 Design and Technology (D\&T) students' group participation had revealed some preliminary findings in terms of different participation rates and that one group out of the three (each group comprises of five members based on cooperative learning classroom practices) showed a relatively high level of in-depth information processing in design stages (Yeo \& Quek, 2008). The difference in group participation further prompted the researchers to investigate how these students interact with their peers in this technology-mediated environment which is the focus of current study. Numerous research studies have highlighted how technology, in particular, asynchronous online technology, is deployed in different cultural contexts to support learner participation and interaction in teaching and learning (Vonderwell, Liang \& Alderman, 2007; Cain \& Pitre, 2008; Offir, Lev \& Bezalel, 2008; Quiroz, 2008). Some of the advantages of using asynchronous online technology to support learners' interaction with peers include gaining of time, space and the permanence of contents as compared to face to face interaction which is restricted by time and physical space constraints (Jonassen \& Kwon, 2001; Ng \& Cheung, 2007; Quiroz, 2008).

Participation is a self-initiated act by an individual in an organised activity occurring within the learning environment. Examples of activities include forum discussion, role play and exchanging views and experiences (Hew \& Cheung, 2008; Hrastinski, 2008). Participation is active learning that helps learners acquire general subject mastery and achieve deep understanding of subject matter through their sharing and evaluating of 
ideas (Black, 2005). Active participation in discussion forums is dependent on the learners' engagement, commitment and contributions in a group, which in turn also influences the learners' behaviours (Ng \& Cheung, 2007; Song \& Hill, 2007; Hrastinski, 2009). From the instructors' perspective, participation is observed by the participants' contributing of ideas, asking of questions and sharing of resources. From the learners' perspective, participation is observed from the learners' level of engagement, motivation and interest. Participation reveals the affective aspect that speaks about the learners' confidence, feeling of being accepted by peers and having a sense of belonging in the community, which in turn provides support to the participants.

According to the social learning theory of Bandura (1977), learning from each other creates a social context which in turn brings about interaction amongst the individuals. Interaction is a communication process between a participant and other participants, in either a face to face or online environment. The inquiry-response-evaluation (IRE) cycle or IRE participant framework is one example of a typical face to face classroom interaction, with a minimum amount of student talk residing primarily at the knowledge level of Bloom's taxonomy (Mercer, 1995). On the contrary, interaction has been found to have direct influences on learners' development of deep understanding in discussion forums. Examples of learning activities taking place in forum discussions include problem solving (Baghaei, Mitrovic \& Irwin, 2007), sharing of opinions among peers and instructors ( $\mathrm{Wu} \&$ Hiltz, 2004), and facilitation of participants' sharing of information and ideas. The group learning goals are accomplished because there is distribution of expertise among group members (Lipponen, Rahikainen, Lallimo \& Hakkarainen, 2003), mutual support for each other in co-construction of knowledge through meaningful discourse (Gilbert \& Dabbagh, 2005; Hull \& Saxon, 2009), and the participants express their knowledge construction process explicitly, thereby helping learners to become aware of that process (Brown \& Campione, 1996).

Cognitive and social interactions occur in communications amongst learners. According to Vygotsky (1978), social interaction plays a fundamental role in the development of cognition, whereby participants learn from each other's sharing of knowledge, skills and experiences. Cognitive interaction refers to a process of shared meaning construction in collaborative activity mediated through designed artefacts (Koschmann, 2002). The artefacts are considered as knowledge objects or ideas which are improved by the collective cognitive responsibility of the learners in the community, through activities such as gathering information from multiple sources and debating about the ideas in discourse (Lamon, Reeve \& Scardamalia, 2001; Scardamalia, 2002). For example, meaning-making is an interaction outcome that is not attributable to individual utterances of individual students, but depends on references made to the shared encounters (Stahl, 2006).

In forum discussions, interaction involves exchanges between learners either by reading or building on each other's notes. Interaction among learners brings about the intention of value adding to individual learning outcomes (Gerber, Grund \& Grote, 2008) and group performance in the context of co-construction of knowledge (Lipponen, Rahikainen, Lallimo \& Hakkarainen, 2001). The exchanges of ideas among learners foster social construction of knowledge, which is key to achieving quality learning (Lave \& Wenger, 1991; Stacey \& Rice, 2002; Schrire, 2006). Effective online interaction often involves a structured approach skilfully designed with a small group of learners (about five to six) who work towards group goals (Graham 2002; Zhang \& Peck, 2003; Rose, 2004; Lapadat, 2007; McCrory, Putnam \& Jansen, 2008). In this study, the research questions were: 
1. To what extent do students participate in a computer-mediated D\&T learning environment?

2. How do students and peers interact in the design process of a computer-mediated D\&T learning environment?

\section{Methodology}

\section{Sample}

The sample consisted of a class of 15 D\&T students (aged 15) from a high school. The class comprised six girls and nine boys who were of slightly above average ability. All of them had access to computers at home. Computers in the school's laboratories were also made available for them to use both during and after school hours. They had no prior experience in asynchronous online discussion and were participating in it for the first time. The online forum discussions took place for seven weeks in this computermediated D\&T learning environment. For this study, online discussion took place at stages of situation, ideation and development. The asynchronous online discussion tool, Knowledge Forum (KF), was chosen on the basis of its potential support for the students' collaborative learning, co-construction of ideas and idea improvement, based on literature reviewed for this study. For example, in such a learning environment, D\&T students assume active roles in their participation and interactions with peers through the use of teacher-facilitator's selected, customised and built in scaffolds in their forum discussions (for example, 'My generalisation', 'My D\&T ideas') for online learning.

\section{Procedure}

The students worked in three groups of five for all the D \&T activities. They were assigned to the groups randomly. Teacher demonstrations and a hands on session were provided for students to learn to use KF. They were provided with a simple discussion topic for the purpose of encouraging social communication among themselves. They were also instructed to read the note entitled "Ground rules" to make them aware of the teacher's expectation of them. For example, they would be expected to participate actively in the discussions and post messages that are related to the discussion topics. A blended approach was adopted in this study. Face to face discussions took place among the members in each group and online discussions involved every participant in the class. Face to face discussions focused on decision making, while the online discussions focused upon idea improvements. The activities were structured and the students were led through the problem solving or design process by the teacher who played the role of facilitator. The stages in the design process are situation, ideation, development and realisation. For this study, we chose to focus on three stages only.

At the situation stage, students were given an ill-defined real world design situation with a design problem embedded in it. Discussion at this stage was focused on identifying the problem and having a better understanding of the design task and its context. Student tasks included identifying design problem and user needs, considering design factors that might affect the design problem, and collecting any other relevant research data. All of these were posted onto the forum for discussion among all participants to discuss and interact with their peers. 
At the ideation stage, every student generated possible solutions to the design task and contributed these to the forum in the form of design ideas. These ideas were evaluated through discussion, interaction and critique by peers in the online environment. Refinements and improvements were progressively made to the ideas. Next, members in each group met face to face to select a final design idea for their group to work on.

At the development stage, the chosen design idea was developed, by all necessary details needed for fabricating the idea being considered and posted to the forum for evaluation by all participants. The members in each group then discussed face to face the selection of the final development details for the making of the product. At the realisation stage, students in each group made their products in the technical workshop. No online discussion was needed at this stage. At the end of these design stages, students were encouraged to reflect on their learning using a "3-2-1 strategy". That is, three things you learnt, two things you found useful and one thing that you have a problem with. The students' online discussion activities are summarised in Table 1. The goal of online discussion was for design ideas to be represented in the form of notes or online messages that require students to inquire and suggest improvements via student interactions in $\mathrm{KF}$.

Table 1: Students' online discussion activities in design stages

\begin{tabular}{|l|l|}
\hline \multicolumn{1}{|c|}{ Design stage } & \multicolumn{1}{c|}{ Students' online discussion activities } \\
\hline Situation & $\bullet \begin{array}{l}\text { Articulation of design situation, identification of design problem and user } \\
\text { needs }\end{array}$ \\
& $\bullet$ Identification of design factors that could affect design solution \\
\hline Ideation & $\bullet$ Generation of possible design ideas \\
& $\bullet \begin{array}{l}\text { Evaluation of possible design ideas } \\
\text { - Selection of final design idea }\end{array}$ \\
\hline Development & $\bullet$ Generation of development details \\
& $\bullet \begin{array}{l}\text { Evaluation of development details } \\
\text { - Selection of final development details }\end{array}$ \\
\hline
\end{tabular}

\section{Data collection and analysis}

Students' data was collected from their online scripts in KF, their documented reflection logs and their design brief, during March-August 2007. In KF, all the students' online participation and interaction in the discussion forum was analysed quantitatively by means of the data generated by the Analytic Toolkit in KF. To elaborate, Analytic Toolkit is a built-in statistical tool that provides a summary of statistics on the notes posted, read, keywords used, interactions and timing of activities of participants involved. Students' individual reflection logs documented their feelings, thoughts, learning encounters — be it difficulties or successes experienced at each stage. Students' design briefs consisted of their justification of design ideas and decision making for their design.

For this case study, we decided to use three sources of data to investigate students' participation and interaction with their peers in D\&T learning. Our chosen working definition of student participation here refers to the number of student-posted messages in the stages of the design process in the discussion forum while Interaction here refers to the number of messages read and built on by each of the students in this D\&T computer-mediated learning environment. 


\section{Findings and discussion}

Research question 1:

To what extent do students participate in the computer-mediated DET learning environment?

The weekly and total participation from each student is tabulated as shown in Table 2. Participation was based on the number of postings made to the discussion forum by each student (names are pseudonyms). There were 7 discussion weeks altogether, being Weeks 1, 3, 4, 5, 19, 20 and 23. There was no participation in all the other weeks due to term tests, semester examinations and term breaks. The graphical representations of the students' weekly and total participation are shown in Figures 1 and 2 respectively.

Table 2: Students' weekly participation

\begin{tabular}{|l|c|c|c|c|c|c|c|c|}
\hline \multirow{2}{*}{$\begin{array}{c}\text { Student } \\
\text { pseudonym) }\end{array}$} & \multicolumn{9}{|c|}{ Weekly student participation } \\
\cline { 2 - 9 } Sarah & Wk 1 & Wk 3 & Wk 4 & Wk 5 & Wk 19 & Wk 20 & Wk 23 & \\
\hline Wong & 0 & 0 & 0 & 0 & 1 & 0 & 0 & $1(0.7)$ \\
\hline Mz & 0 & 1 & 0 & 1 & 0 & 0 & 0 & $2(1.5)$ \\
\hline Aiman & 0 & 0 & 0 & 1 & 0 & 0 & 3 & $4(2.9)$ \\
\hline Han & 1 & 0 & 1 & 0 & 0 & 0 & 3 & $5(3.7)$ \\
\hline Leong & 0 & 0 & 4 & 0 & 1 & 0 & 0 & $5(3.7)$ \\
\hline Mk & 0 & 1 & 0 & 2 & 0 & 2 & 0 & $5(3.7)$ \\
\hline Akmal & 2 & 0 & 0 & 3 & 0 & 0 & 2 & $7(5.1)$ \\
\hline Nurul & 2 & 2 & 0 & 2 & 0 & 0 & 2 & $8(5.8)$ \\
\hline Gan & 2 & 2 & 4 & 0 & 0 & 0 & 1 & $9(6.5)$ \\
\hline Heng & 0 & 4 & 6 & 1 & 0 & 0 & 0 & $11(8)$ \\
\hline Low & 3 & 0 & 3 & 1 & 0 & 0 & 4 & $11(8)$ \\
\hline Aw & 1 & 0 & 6 & 2 & 1 & 4 & 2 & $16(11.7)$ \\
\hline Chen & 2 & 0 & 8 & 1 & 0 & 5 & 5 & $21(15.3)$ \\
\hline Leow & 2 & 6 & 6 & 1 & 2 & 7 & 3 & $27(19.7)$ \\
\hline Total $(\%)$ & $15(10.9)$ & $18(13.1)$ & $38(27.8)$ & $18(13.1)$ & $5(3.7)$ & $18(13.1)$ & $25(18.3)$ & $137(100)$ \\
\hline
\end{tabular}



Figure 1: Graphical representation of weekly student participation 
With a total contribution of 137 messages from 15 students over 7 weeks, the average contribution is about 1.3 messages per student each week. This is a low participation rate in comparison with 1.48 and 2.33 contributions in studies by Schellen and Valcke (2005) and Sing and Khine (2006) respectively. The total participation from each student ranges from $1(0.7 \%)$ to $27(19.7 \%)$ postings. A 'free rider' effect (Janssen, Erkens, Kanselaar \& Jaspers, 2006) was apparent in some of the students, most notably Sarah and Wong who contributed only one and two postings respectively throughout the whole discussion. These students were probably depending on others to do the work. The use of contextual real world problems did not seem to motivate these students to participate actively in the discussion. On the other hand, the students named Leow and Chen made a total of $27(19.7 \%)$ and $21(15.3 \%)$ postings respectively. This averages about 4 postings for Leow and 3 postings for Chen per week.



Figure 2: Graphical representation of total student participation

In terms of weekly contribution, there is obvious participation inequality in the students. With the exception of Leow who contributed every week, all the other students were not consistent in their weekly participation. The total weekly participation from all the students shows that contributions started moderately at week 1 with $15(10.9 \%)$ postings. Contributions then increased and peaked at week 4 with $38(27.8 \%)$ postings before sliding down to $5(3.7 \%)$ postings at week 19 . Contributions picked up again from here and it reached its second peak of $25(18.3 \%)$ postings at week 23 which was the last week of discussion. The students could be new to the learning environment at week 1 and were hesitant about posting messages to the forum. As they accustomed themselves with the online discussion, message contributions started to pick up and reached a maximum at week 4 .

Students began to participate but the frequency slowed down at week 5 as school examinations and semester holidays approached from week 6 to week 18. Participation at week 19 was sluggish after this long break. It picked up again from here and 
reached another high level at week 23. Students could be rushing to complete the discussion before the final deadline at week 23 .

Research question 2:

How do students and peers interact in the design process of computer-mediated DET learning environment?

Student-student interactions based on notes read and built on are tabulated as shown in Table 3 and Table 4 respectively. Representations of the data in Tables 3 and 4 in the form of social networks are shown in Figures 3 and 4 respectively.

Table 3: Frequency of notes read by students

\begin{tabular}{|l|c|c|c|c|c|c|c|c|c|c|c|c|c|c|c|c|}
\hline Student & Mz & Mk & Leong & Gan & Chen & Akmal & Aiman & Sarah & Nurul & Leow & Wong & Low & Heng & Han & Aw & Total \\
\hline Mz & $\mathrm{x}$ & 2 & 0 & 1 & 0 & 2 & 2 & 0 & 0 & 3 & 0 & 1 & 1 & 1 & 0 & 13 \\
\hline Mk & 0 & $\mathrm{x}$ & 0 & 0 & 0 & 1 & 0 & 0 & 1 & 1 & 0 & 2 & 0 & 0 & 0 & 5 \\
\hline Leong & 0 & 2 & $\mathrm{x}$ & 3 & 6 & 0 & 0 & 0 & 0 & 0 & 0 & 3 & 0 & 0 & 11 & 25 \\
\hline Gan & 0 & 1 & 2 & $\mathrm{x}$ & 4 & 1 & 0 & 0 & 1 & 5 & 0 & 3 & 0 & 4 & 12 & 33 \\
\hline Chen & 1 & 3 & 3 & 4 & $\mathrm{x}$ & 0 & 2 & 2 & 2 & 20 & 0 & 8 & 2 & 3 & 12 & 62 \\
\hline Akmal & 1 & 3 & 0 & 0 & 0 & $\mathrm{x}$ & 1 & 0 & 2 & 2 & 0 & 0 & 2 & 0 & 0 & 11 \\
\hline Aiman & 0 & 0 & 0 & 0 & 0 & 0 & $\mathrm{x}$ & 0 & 0 & 0 & 0 & 0 & 0 & 0 & 0 & 0 \\
\hline Sarah & 0 & 0 & 0 & 0 & 0 & 0 & 0 & $\mathrm{x}$ & 0 & 0 & 0 & 0 & 0 & 0 & 0 & 0 \\
\hline Nurul & 0 & 1 & 0 & 1 & 1 & 4 & 0 & 0 & $\mathrm{x}$ & 4 & 0 & 1 & 0 & 0 & 1 & 13 \\
\hline Leow & 2 & 0 & 5 & 7 & 17 & 2 & 3 & 0 & 4 & $\mathrm{x}$ & 1 & 4 & 20 & 9 & 15 & 89 \\
\hline Wong & 0 & 0 & 0 & 0 & 0 & 0 & 0 & 0 & 0 & 0 & $\mathrm{x}$ & 0 & 0 & 0 & 0 & 0 \\
\hline Low & 0 & 2 & 0 & 5 & 1 & 0 & 0 & 0 & 0 & 6 & 0 & $\mathrm{x}$ & 2 & 0 & 6 & 22 \\
\hline Heng & 0 & 1 & 2 & 6 & 2 & 2 & 3 & 0 & 0 & 19 & 0 & 3 & $\mathrm{x}$ & 3 & 1 & 42 \\
\hline Han & 2 & 1 & 1 & 1 & 2 & 0 & 1 & 0 & 0 & 13 & 0 & 2 & 10 & $\mathrm{x}$ & 3 & 36 \\
\hline Aw & 0 & 2 & 1 & 4 & 5 & 0 & 1 & 0 & 1 & 12 & 0 & 3 & 3 & 1 & $\mathrm{x}$ & 33 \\
\hline Total & 6 & 18 & 14 & 32 & 38 & 12 & 13 & 2 & 11 & 85 & 1 & 30 & 40 & 21 & 61 & 384 \\
\hline
\end{tabular}

The numbers in the tables represent the frequency of notes written by the students in the first row that are read or built on by the students in the first column. In Table 3, for example, the first student in the first column named $\mathrm{Mz}$ has read $\mathrm{Mk}^{\prime}$ s notes twice, Gan's notes once, Akmal's notes twice, and so on. Interpreted similarly in Table 4, the student Mz has not built on any other students' notes whereas student Mk has built on Low's notes once.

The large difference between frequency of notes read and notes built on is most apparent from Tables 3 and 4 and Figures 3 and 4 . In total, the students have read 384 notes but have built on only 43 notes. The students could have found reading notes to be simpler and more convenient than writing notes. The total of 137 messages contributed by students were read 384 times. This could imply that each message posting was read 2.8 times. Also, out of the total of 137 messages contributed by students, $43(31 \%)$ of them were built on message postings. Again, this could have the implication that for every three notes contributed, one of them was a built on note.

In Table 3, with the exception of Aiman, Sarah and Wong who did not read any note, all the others have read notes written by other students. The student named Mk has read notes the least number of times (5 times) and Leow has read notes the most number of times (89 times). The last row of the table shows that all the students' notes have been read at least once. Notes written by Wong and Sarah were least read by others. Notes written by Wong were read only once whereas the only note written by Sarah was read twice. Notes written by Leow were read 85 times by others, and this is 
the highest number of all the students. As far as reading notes is concerned, Leow was the most active and she could have gained the most from the reading activity. Her notes were also most read, totalling 85 times.

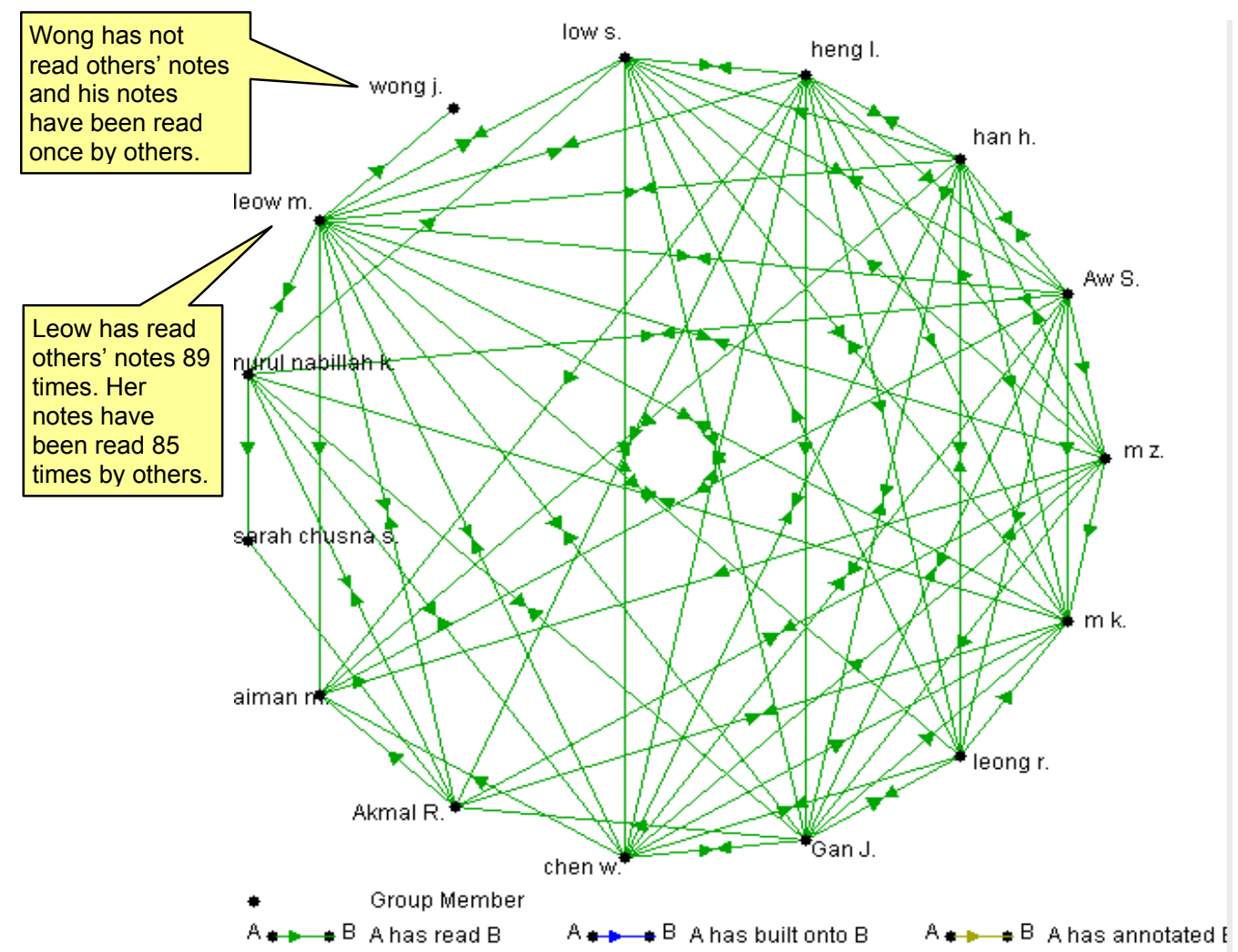

Figure 3: Social network of notes read

Table 4: Frequency of notes built-on by students

\begin{tabular}{|l|c|c|c|c|c|c|c|c|c|c|c|c|c|c|c|c|}
\hline Student & $\mathrm{Mz}$ & $\mathrm{Mk}$ & Leong & Gan & Chen & Akmal & Aiman & Sarah & Nurul & Leow & Wong & Low & Heng & Han & Aw & Total \\
\hline $\mathrm{Mz}$ & $\mathrm{x}$ & 0 & 0 & 0 & 0 & 0 & 0 & 0 & 0 & 0 & 0 & 0 & 0 & 0 & 0 & 0 \\
\hline Mk & 0 & $\mathrm{x}$ & 0 & 0 & 0 & 0 & 0 & 0 & 0 & 0 & 0 & 1 & 0 & 0 & 0 & 1 \\
\hline Leong & 0 & 0 & $\mathrm{x}$ & 1 & 1 & 0 & 0 & 0 & 0 & 0 & 0 & 0 & 0 & 0 & 1 & 3 \\
\hline Gan & 0 & 0 & 0 & $\mathrm{x}$ & 1 & 0 & 0 & 0 & 0 & 0 & 0 & 1 & 0 & 0 & 0 & 2 \\
\hline Chen & 0 & 1 & 0 & 2 & $\mathrm{x}$ & 0 & 0 & 0 & 1 & 3 & 0 & 1 & 1 & 1 & 2 & 12 \\
\hline Akmal & 0 & 0 & 0 & 0 & 0 & $\mathrm{x}$ & 0 & 0 & 0 & 1 & 0 & 0 & 0 & 0 & 0 & 1 \\
\hline Aiman & 0 & 0 & 0 & 0 & 0 & 0 & $\mathrm{x}$ & 0 & 0 & 0 & 0 & 0 & 0 & 0 & 0 & 0 \\
\hline Sarah & 0 & 0 & 0 & 0 & 0 & 0 & 0 & $\mathrm{x}$ & 0 & 0 & 0 & 0 & 0 & 0 & 0 & 0 \\
\hline Nurul & 0 & 0 & 0 & 0 & 0 & 0 & 0 & 0 & $\mathrm{x}$ & 0 & 0 & 0 & 0 & 0 & 0 & 0 \\
\hline Leow & 0 & 0 & 0 & 1 & 3 & 0 & 0 & 0 & 0 & $\mathrm{x}$ & 0 & 0 & 5 & 2 & 1 & 12 \\
\hline Wong & 0 & 0 & 0 & 0 & 0 & 0 & 0 & 0 & 0 & 0 & $\mathrm{x}$ & 0 & 0 & 0 & 0 & 0 \\
\hline Low & 0 & 1 & 0 & 1 & 0 & 0 & 0 & 0 & 0 & 0 & 0 & $\mathrm{x}$ & 0 & 0 & 0 & 2 \\
\hline Heng & 0 & 0 & 0 & 1 & 0 & 0 & 0 & 0 & 0 & 1 & 0 & 0 & $\mathrm{x}$ & 1 & 0 & 3 \\
\hline Han & 0 & 0 & 0 & 0 & 0 & 0 & 0 & 0 & 0 & 1 & 0 & 0 & 0 & $\mathrm{x}$ & 0 & 1 \\
\hline Aw & 0 & 0 & 0 & 3 & 1 & 0 & 0 & 0 & 0 & 1 & 0 & 1 & 0 & 0 & $\mathrm{x}$ & 6 \\
\hline Total & 0 & 2 & 0 & 9 & 6 & 0 & 0 & 0 & 1 & 7 & 0 & 4 & 6 & 4 & 4 & 43 \\
\hline
\end{tabular}




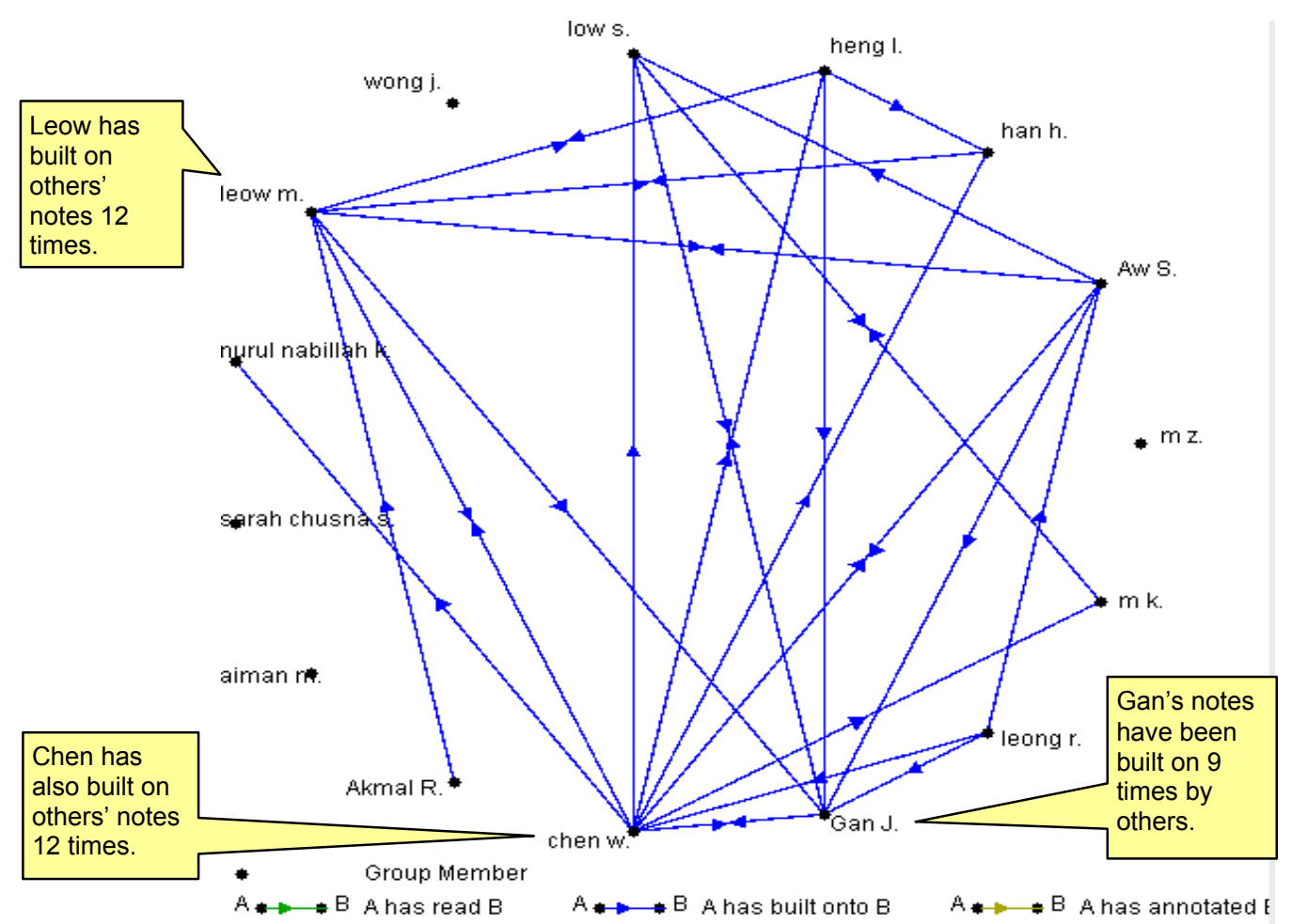

Figure 4: Social network of notes built on

Table 4 shows that five of the students did not build on to any of the notes written by others. These five students were Mz, Aiman, Sarah, Nurul and Wong. Students Chen and Leow built on the most number of notes. Each of them built on 12 notes which was the highest number of all. In fact, the total built on notes by just these two students accounted for over $50 \%$ of the total built on notes. Most of the interaction was dependent on these two students. Six of the students' notes were not built on by others as shown in the last row of the table. These students were Mz, Leong, Akmal, Aiman, Sarah and Wong. Notes written by Gan and Leow were built on most number of times by others. Student Gan has his notes built on 9 times while Leow has her notes built on 7 times by others. As far as building on of notes is concerned, there is considered to be a lack of interaction among the students.

A point about social networks to be highlighted in this study is that of network density. The social networks in Figures 3 and 4 show the connections among the students in terms of reading of notes and building on notes respectively. Each line in the networks represents a connection between two students. In Figure 3, for example, there is a connection between Leow and Wong with the arrow pointing towards Wong. This indicates that Leow has read Wong's notes. Similarly in Figure 4, there is a connection between Heng and Han with the arrow pointing towards Han. This indicates that Heng has built on Han's notes. Network density is the ratio of actual number of connections to the total possible number of connections, which is also an indication of the volume of connections in the networks. 
The total possible number of connections in a network with 15 students is 105 . For the social network of notes read in Figure 3, the actual number of connections is 66 . The density is therefore 0.63 or $63 \%$. For the social network of notes built on in Figure 4 , the actual number of connections is 22 . The density is therefore 0.21 or $21 \%$. The density of $63 \%$ for the network of notes read is considered high (Lipponen et al., 2003). This is an indication of high interaction among the students in reading of each other's notes. On the other hand, the density of $21 \%$ for the network of notes built on shows that it is a sparse network. There is certainly a lack of interaction among the students as far as building on each other's notes is concerned.

\section{Conclusion}

This study has explored 15 D\&T student peers' interactions in a computer-mediated environment. From a contextual real world design situation given at the beginning of the activities, the students have worked through stages of situation, ideation and development of the design process to arrive at solutions to a design problem identified in the situation. The study has been designed such that online discussion involved participation from all 15 participants. The goal was to have the diverse perspectives of the participants resulting in effective interactions among peers that would in turn lead to improvement of design ideas.

Two aspects of 15 students' participation were investigated as one community in this study. In terms of these students' participation based on message contribution, there were a total of 137 message postings. In terms of participation based on equality, there was a considerable difference between the most active and least active participants in their quantity of postings. Even though no lurkers were present, more than half of the number of students contributed less than 10 postings in all the forum discussion. From their reflection logs, it was revealed that these students might have thought that others who were active in their participation could do all the work and so they had left the responsibility entirely to them. This could also be a problem resulting from too big an online discussion group of 15 participants. There could be a lack of accountability in the students due to such a big group. Inequality in participation could lead to low productivity and quality of achievement. The weekly participation pattern shows that the frequent breaks seemed to have affected participation as well.

At the community level, 15 students and their peers' interactions were investigated based on notes read and notes built on by students. The total number of notes read far exceeded the total number of notes built on by almost 9 times. Participants could have found reading of notes to be more comfortable than writing notes. With the exception of three students who did not read a single note, all the others have read notes written by others. Four-fifths of the students have built on less than 4 notes in the whole discussion. Discussion through building on of notes seemed to be sustained by the remaining one-fifth of the students in the class. This has certainly reduced the rigour of interaction in the online discussion and could have an adverse effect on the learning outcome. A lack of facilitation skill on the part of the teacher could have resulted in the limited interaction among the students. Perhaps the teacher needed to be more reflective about the new learning environment, monitoring his own teaching in terms of where and in what manner he could increase the level of student interaction (Johnson, 2007; Quek, 2009). Alternatively, the facilitators needed to determine how interaction rules could be reinforced in the computer-mediated D\&T learning environment. 
Findings from this study have shown that technology mediation in the form of asynchronous discussion tool has supported student' interactions with their peers. Pedagogically, this is one of the forms of student centred learning that is worthy for curriculum designers to consider alternative pathway for more diversity of student centred learning in D\&T as compared to the traditional pedagogical approach of using 'paper and pencil' in D\&T teaching and learning. Although students' brainstormed ideas have been evident in the 'built on' and 'read by' stages of D\&T learning, there are issues to be addressed in terms of student participation and peers' interactions.

For a big group size such as 15 in this study, close monitoring by the teacher-facilitator would be crucial in order to prevent or reduce the likelihood of participation inequality. In retrospect, the group size in the discussion could be reduced to increase member accountability within each group so that each member has the opportunity to contribute to group processes and knowledge construction in the group. Equality and increase in participation in a well-designed and facilitated online learning environment would help to enhance discussion leading to more effective interaction in terms of both reading and building on notes. The optimal group size of students involved in the asynchronous online discussion in D\&T could be explored as a follow up study. Future studies should look also into the depth of interaction, perhaps to analyse the degree of coherence and convergence as well as the construction of knowledge by the students. This may also be dependant on facilitator skills (Chai \& Khine, 2006; McPherson \& Nunes, 2008), which need to be further developed.

\section{References}

Baghaei, N., Mitrovic, A. \& Irwin, W. (2007). Supporting collaborative learning and problem solving in a constraint-based CSCL environment for UML class diagrams. International Journal of Computer-Supported Collaborative Learning, 2(2-3), http: / / dx.doi.org/ 10.1007/ s11412-007-9018-0

Bandura, A. (1977). Social learning theory. New York: General Learning Press.

Black, A. (2005). The use of asynchronous discussion: Creating a text of talk. Contemporary Issues in Technology and Teacher Education, 5(1).

http: / / www.citejournal.org/vol5/iss1/languagearts/article1.cfm

Brown, A. L. \& Campione, J. C. (1996). Psychological theory and the design of innovative learning environments: On procedures, principles, and systems. In L. Schauble \& R. Glaser (Eds.), Innovations in learning: New environments for education (pp. 289-325). Mahwah, NJ: Erlbaum.

Cain, D. L. \& Pitre, P. E. (2008). The effect of computer mediated conferencing and computer assisted instruction on student learning outcomes. Journal of Asynchronous Learning Networks, 12(3-4). 31-52. http: / / sloanconsortium.org/sites / default/ files/v12n3_cain_0.pdf

Chai, C. S. \& Khine, M. S. (2006). An analysis of interaction and participation patterns in online community. Educational Technology \& Society, 9(1), 250-261. http: / / www.ifets.info/download_pdf.php?j_id=30\&a_id=616

Gerber, M., Grund, S. \& Grote, G. (2008). Distributed collaboration activities in a blended learning scenario and the effects on learning performance. Journal of Computer Assisted Learning, 24(3), 232-244. http:/ / dx.doi.org/10.1111/j.1365-2729.2007.00256

Gilbert, P. K. \& Dabbagh, N. (2005). How to structure online discussions for meaningful discourse: A case study. British Journal of Educational Technology, 36(1), 5-18. http: / / onlinelibrary.wiley.com/ doi/10.1111/j.1467-8535.2005.00434.x 
Graham, C. R. (2002). Understanding and facilitating computer-mediated teamwork: A study of how norms develop in online learning teams. Unpublished $\mathrm{PhD}$ thesis, Indiana University, Bloomington.

Hew, K. F. \& Cheung, W. S. (2008). Attracting student participation in asynchronous online discussions: A case study of peer facilitation. Computers $\mathcal{E}$ Education, 51(3), 1111-1124. http:/ / dx.doi.org/10.1016/j.compedu.2007.11.002

Hrastinski, S. (2008). What is online learner participation? A literature review. Computers $\mathcal{E}$ Education, 51(4), 1755-1765. http: / / dx.doi.org/10.1016/j.compedu.2008.05.005

Hrastinski, S. (2009). A theory of online learning as online participation. Computers E Education, 52(1), 78-82. http:/ / dx.doi.org/10.1016/j.compedu.2008.06.009

Hull, D. M. \& Saxon, T. F. (2009). Negotiation of meaning and co-construction of knowledge: An experimental analysis of asynchronous online instruction. Computers $\mathcal{E}$ Education, 52(3), 624639. http:/ / dx.doi.org/10.1016/j.compedu.2008.11.005

Johnson, E. S. (2007). Promoting learner-learner interactions through ecological assessments of the online environment. Journal of Online Learning and Teaching, 3(2). 142-154. http: / / jolt.merlot.org/vol3no2/ johnson.htm

Jonassen, D. H. \& Kwon, H. I. (2001). Communication patterns in computer mediated versus face-to-face group problem solving. Educational Technology Research E Development, 49(1), 3551. http: / / dx.doi.org/10.1007/BF02504505

Koschmann, T. (2002). Dewey's contribution to the foundations of CSCL research. Proceedings Computer Supported Collaborative Learning 2002, Boulder, January 7-11, pp. 17-22. http: / / portal.acm.org / citation.cfm?id=1658618\&dl=ACM\&coll=DL\&CFID=32599583\&CFT OKEN=97979995

Lamon, M., Reeve, R. \& Scardamalia, M. (2001). Mapping learning and the growth of knowledge in a knowledge building community. Paper presented at the American Educational Research Association Meeting, Seattle, USA. Washington. [verified 7 Jul 2011] http: / / ikit.org/lamon/ mapping.html

Lapadat, J. C. (2007). Discourse devices used to establish community, increase coherence and negotiate agreement in an online university course. The Journal of Distance Education, 21(3), 59-92. http: / / www.eric.ed.gov:80/ ERICWebPortal/ contentdelivery / servlet/ ERICServlet? accno=EJ805057

Lave, J. \& Wenger, E. (1991). Situated learning: Legitimate peripheral participation. Cambridge: Cambridge University Press.

Lipponen, L., Rahikainen, M., Lallimo, J. \& Hakkarainen, K. (2001). Analyzing patterns of participation and discourse in elementary students' online science discussion. In P. Dillenbourg, A. Eurelings \& K. Hakkarainen (Eds.), European perspectives on computersupported collaborative learning. The proceedings of the First European Conference on ComputerSupported Collaborative Learning (pp.421-428). University of Maastricht. [verified 7 Jul 2011] http: / / www.eculturenet.org/mmi/ euro-cscl/ Papers/102.doc

Lipponen, L., Rahikainen, M., Lallimo, J. \& Hakkarainen, K. (2003). Patterns of participation and discourse in elementary students' computer-supported collaborative learning. Learning and Instruction, 13(5), 487-509. http: / / dx.doi.org/10.1016/S0959-4752(02)00042-7

Mayes, T. \& de Freitas, S. (2004). JISC e-Learning Models Desk Study. Stage 2: Review of elearning theories, frameworks and models. UK: Joint Information Systems Committee. [verified 7 Jul 2011] http:/ / www.jisc.ac.uk/uploaded_documents/Stage\%202\%20Learning $\%$ 20Models\%20(Version\%201).pdf 
McCrory, R., Putnam, R. \& Jansen, A. (2008). Interaction in online courses for teacher education: Subject matter and pedagogy. Journal of Technology and Teacher Education, 16(2), 155-180. http: / / www.editlib.org/p/23570

Mercer, N.(1995). The guided construction of knowledge: Talk amongst teachers and learners. Clevedon, UK: Multilingual Matters.

McPherson, M. A. \& Nunes, J. M. (2008). Critical issues for e-learning delivery: What may seem obvious is not always put into practice. Journal of Computer Assisted Learning, 24(5), 433-445. http: / / onlinelibrary.wiley.com/doi/ 10.1111/j.1365-2729.2008.00281.x/ abstract

$\mathrm{Ng}$, S. L. C. \& Cheung, W. S. (2007). Comparing face to face, tutor led discussion and online discussion in the classroom. Australasian Journal of Educational Technology, 23(4), 455-469. http: / / www.ascilite.org.au/ajet/ajet23/ng.html

Offir, B., Lev, Y. \& Bezalel, R. (2008). Surface and deep learning processes in distance education: Synchronous versus asynchronous systems. Computers \& Education, 51(3), 1172-1183. http: / / dx.doi.org/10.1016/j.compedu.2007.10.009

Quek, C. L. (2009). Designing a computer-supported project-based learning environment for high school students: A case study. Journal for Computing Teachers, 2009(Spring). http: / / www.iste.org/Store/ Product.aspx?ID=1654

Quiroz, J. S. (2008). Teachers' interactions in a virtual learning environment: A comprehensive approach. Interactive Educational Multimedia, 16, 66-86. http:/ / greav.ub.edu/der/index.php/der/article/view/151/274

Rose, M. A. (2004). Comparing productive online dialogue in two group styles: Cooperative and collaborative. American Journal of Distance Education, 18(2), 73-88. http: / / www.tandfonline.com/doi/abs/10.1207/s15389286ajde1802_2

Scardamalia, M. (2002). Collective cognitive responsibility for the advancement of knowledge. In B. Smith (Ed.), Liberal education in a knowledge society, Chicago, IL, USA: Open Court, 76-98.

Schellens, T. \& Valcke, M. (2005). Collaborative learning in asynchronous discussion groups: What about the impact on cognitive processing? Computers in Human Behaviour, 21(6), 957976. http:/ / dx.doi.org/10.1016/j.chb.2004.02.025

Schrire, S. (2006). Knowledge building in asynchronous discussion groups: Going beyond quantitative analysis. Computers \& Education, 46(1), 49-70. http: / / dx.doi.org/10.1016/j.compedu.2005.04.006

Song, L. \& Hill, J., R. (2007). A conceptual model for understanding self-directed learning in online environment. Journal of Interactive Online Learning, 6(1), 27-42. http: / / www.ncolr.org/jiol/issues/pdf/6.1.3.pdf

Stacey, E. \& Rice, M. (2002). Evaluating an online learning environment. Australian Journal of Educational Technology, 18(3), 323-340. http:/ / www.ascilite.org.au/ajet/ajet18/stacey.html

Stahl, G. (2006). Group cognition: Computer support for building collaborative knowledge. Cambridge, MA: MIT Press. (viewed 10 Mar 2009, verified 7 Jul 2011; preprint version] http:// www.gerrystahl.net/mit/

Vonderwell, S., Liang, X. \& Alderman, K. (2007). Asynchronous discussions and assessment in online learning. Journal of Research on Technology in Education, 39(3), 309-328. [verified 7 Jul 2011] http:/ / www.eric.ed.gov:80/ERICWebPortal/ contentdelivery/ servlet/ ERICServlet? accno $=$ EJ768879

Vygotsky, L. (1978). Mind in society. Harvard University Press, Cambridge, Massachusetts. 
Wu, D. \& Hiltz, S. R. (2004). Predicting learning from asynchronous online discussions. Journal of Asynchronous Learning Networks, 8(2), 139-152.

http: / / sloanconsortium.org/sites/default/files/v8n2_wu_1.pdf

Yeo, T. M. \& Quek, C. L. (2008). Investigating design and technology students' participation and learning in a technology mediated learning environment. Australasian Journal of Educational Technology, 24(5), 540-555. http:/ / www.ascilite.org.au/ajet/ajet24/yeo.html

Zhang, K. \& Peck, K. L. (2003). The effects of peer-controlled or moderated online collaboration on group problem solving and related attitudes. Canadian Journal of Learning and Technology, 29(3). http: / / www.cjlt.ca/index.php/cjlt/article/viewArticle/91/ 85

Authors: Yeo Tiong Meng, Design \& Technology, Marsiling Secondary School, 12 Marsiling Road, Singapore 739110. Email: yeo_tiong_meng@moe.edu.sg

Associate Professor Quek Choon Lang, Learning Sciences \& Technologies, National Institute of Education, Nanyang Technological University, Nanyang Avenue, Singapore 639798. Email: choonlang.quek@nie.edu.sg

Please cite as: Yeo, T. M. \& Quek, C. L. (2011). Investigating design and technology students' peer interactions in a technology-mediated learning environment: A case study. Australasian Journal of Educational Technology, 27(4), 751-764.

http: / / www.ascilite.org.au / ajet/ajet27 / yeo.html 